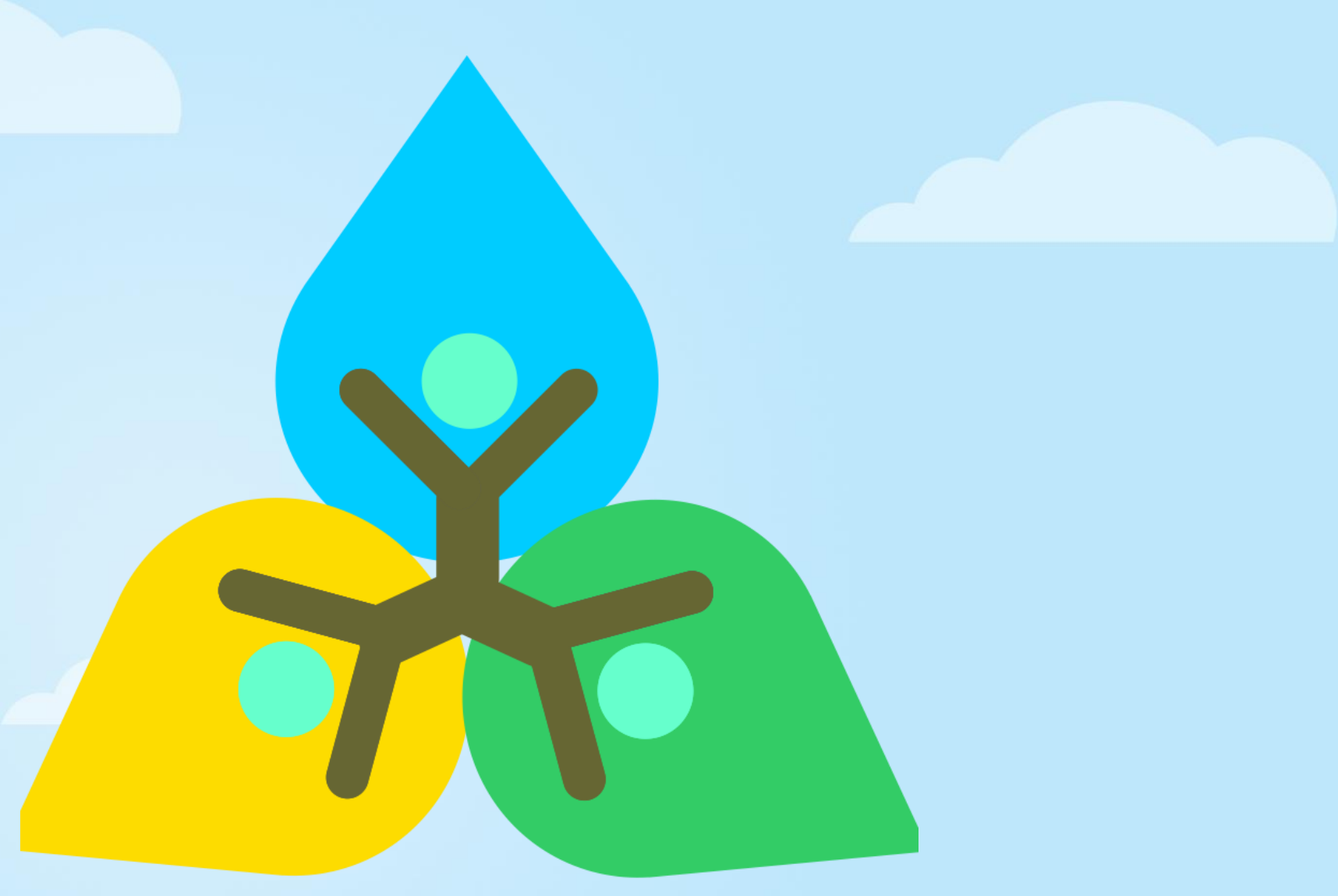




\title{
MENUJU PARIWISATA TANGGUH BENCANA MELALUI ANALISIS HIDROGRAF BANJIR DI SISTEM KARST GOA PINDUL, KABUPATEN GUNUNGKIDUL
}

\author{
Afid Nurkholis \\ afidnurkholis@gmail.com \\ Fakultas Geografi, Universitas Gadjah Mada
}

\section{A. Interpretasi Data}

Sistem Karst Goa Pindul yang terletak di Kecamatan Karangmojo, Kabupaten Gunungkidul memiliki keunikan tersendiri. Bagian utara sistem ini memiliki goa-goa yang saling terhubung. Bagian selatan sistem ini didominasi oleh aliran permukaan yang kemudian tertelan menjadi aliran bawah permukaan (Gambar 1). Agniy (2016) melakukan klasifikasi terhadap dua bagian sistem diatas menjadi akuifer conduit pada bagian utara dan akuifer diffuse-fissure pada bagian selatan.

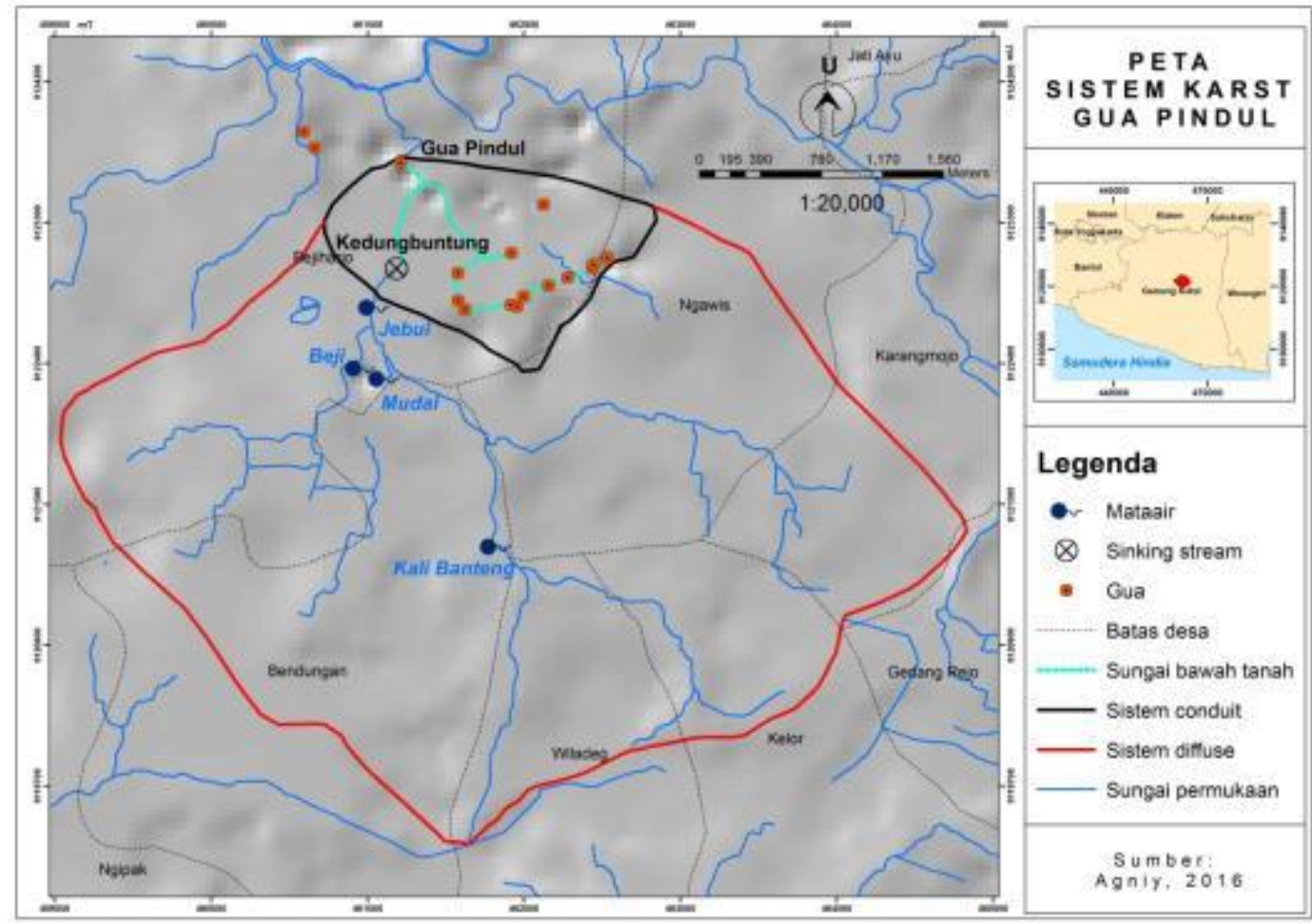

Gambar 1. Peta Sistem Karst Goa Pindul (Agniy, 2016)

Aktivitas manusia telah intensif memanfaatkan wilayah sistem karst ini. Obyek wisata Goa Pindul dan Goa Tanding merupakan aktivitas manusia yang paling dominan. Wisata alam Goa Pindul mampu menarik sejumlah 122.423 
wisatawan dan menyumbang 50\% dari total Pendapatan Asli Daerah (PAD) sektor pariwisata pada periode 2012-2013 (Musadad, 2014). Berbeda dengan Wisata Goa Pindul yang telah menjadi primadona sejak kemunculannya pada tahun 2010, Wisata Goa Tanding baru saja dibuka pada 7 Juli 2016 (http://goatanding.com). Menurut Subagyo selaku Ketua Pemuda Sadar Wisata (POKDARWIS) Desa Bejiharjo, investasi dalam pembangunan Wisata Goa Tanding mencapai 1 miliar Rupiah.

Selain potensi ekonomi yang dimiliki diatas, letak kedua destinasi wisata yang berada di kawasan karst menjadikannya memiliki ancaman bencana. Goa Pindul terletak pada outlet Sistem Karst Pindul, sedangkan Goa Tanding terletak tepat setelah Sinking Stream Kedungbuntung (Gambar 1 dan 2). Posisi kedua obyek tersebut menjadikannya rawan terhadap banjir yang membahayakan wisatawan.
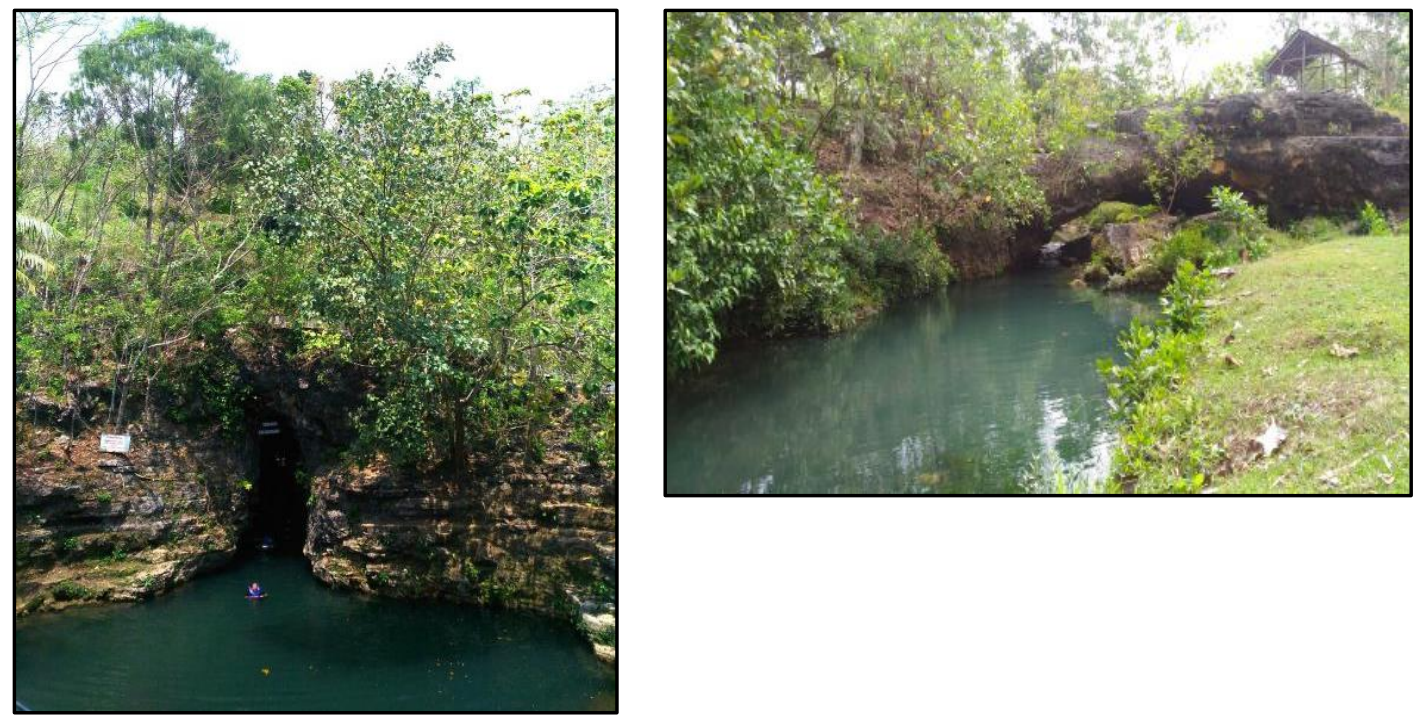

Gambar 2. Outlet Sistem Karst Pindul (kiri) dan Sinking Stream Kedungbuntung (kanan) (Dokumentasi Pribadi, 2016)

Kawasan karst memiliki ciri aliran permukaan yang jarang dan dominannya aliran bawah permukaan (sungai bawah tanah) (Ford \& Williams, 2008; White, 1988). Oleh karena itu, luapan sungai bawah tanah dari Sinking stream Kedungbuntung dan outlet sistem karst dapat terjadi setiap saat ketika hujan deras turun. Menurut situs http://infogunungkidul.com, Goa Pindul mengalami kejadian banjir pada Sabtu, 24 September 2016 akibat hujan deras selama satu jam (Gambar 3). Sementara itu, observasi lapangan pada Sabtu, 8 Oktober 2016 juga 
menunjukkan bahwa Goa Pindul kembali mengalami kejadian banjir. Meskipun kedua kejadian tersebut tidak menimbulkan korban jiwa, bahaya banjir terhadap kedua aktivitas pariwisata tetap tidak terelakkan.

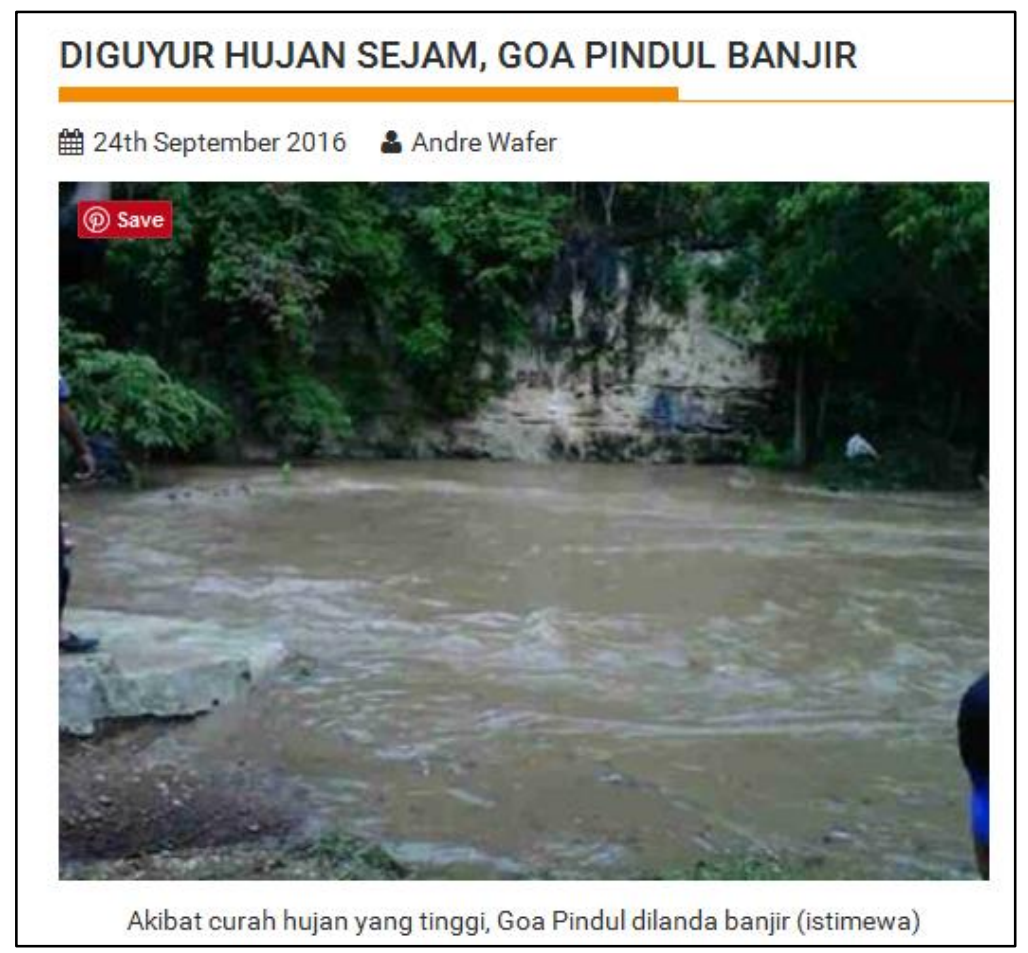

Gambar 3. Banjir Goa Pindul (http://infogunungkidul.com/diguyur-hujan-sejamgoa-pindul-banjir/)

Interpretasi Peta RBI Lembar Wonosari dan Karangmojo Tahun 1998 yang divalidasi menggunakan citra Geo Eye Tahun 2015 menunjukkan bahwa permukiman dan pertanian merupakan aktivitas manusia yang juga dominan. Tegalan/Kebun memiliki luas 60,7\%, sawah memiliki luas 7,3\%, dan permukiman memiliki luas $32 \%$. Seluruh aktivitas tersebut menggunakan sumberdaya airtanah Sistem Karst Pindul. Selain itu, permukiman dan pertanian juga berpotensi mencemari sumberdaya air melalui limbah yang dihasilkannya. Oleh karena itu, aktivitas-aktivitas manusia tersebut berpotensi merusak sumberdaya air dalam segi kuantitas dan kualitas.

\section{B. Penjabaran Program}

Ancaman bencana banjir dan degradasi sumberdaya air di Sistem Karst Pindul masih kurang diperhatikan. Hal ini dapat dilihat melalui program-program atau kegiatan yang dikerjakan oleh pemerintah atau lembaga nonpemerintah. Studi pustaka menunjukkan bahwa program-program yang telah dijalankan lebih 
menekankan terhadap aspek pengembangan pariwisata. Perhatian terhadap manajemen sumberdaya air dan bencana banjir masih rendah. Program-program yang telah dijalankan tersebut diantaranya adalah:

\section{Pembuatan Dokumen UKL/UPL}

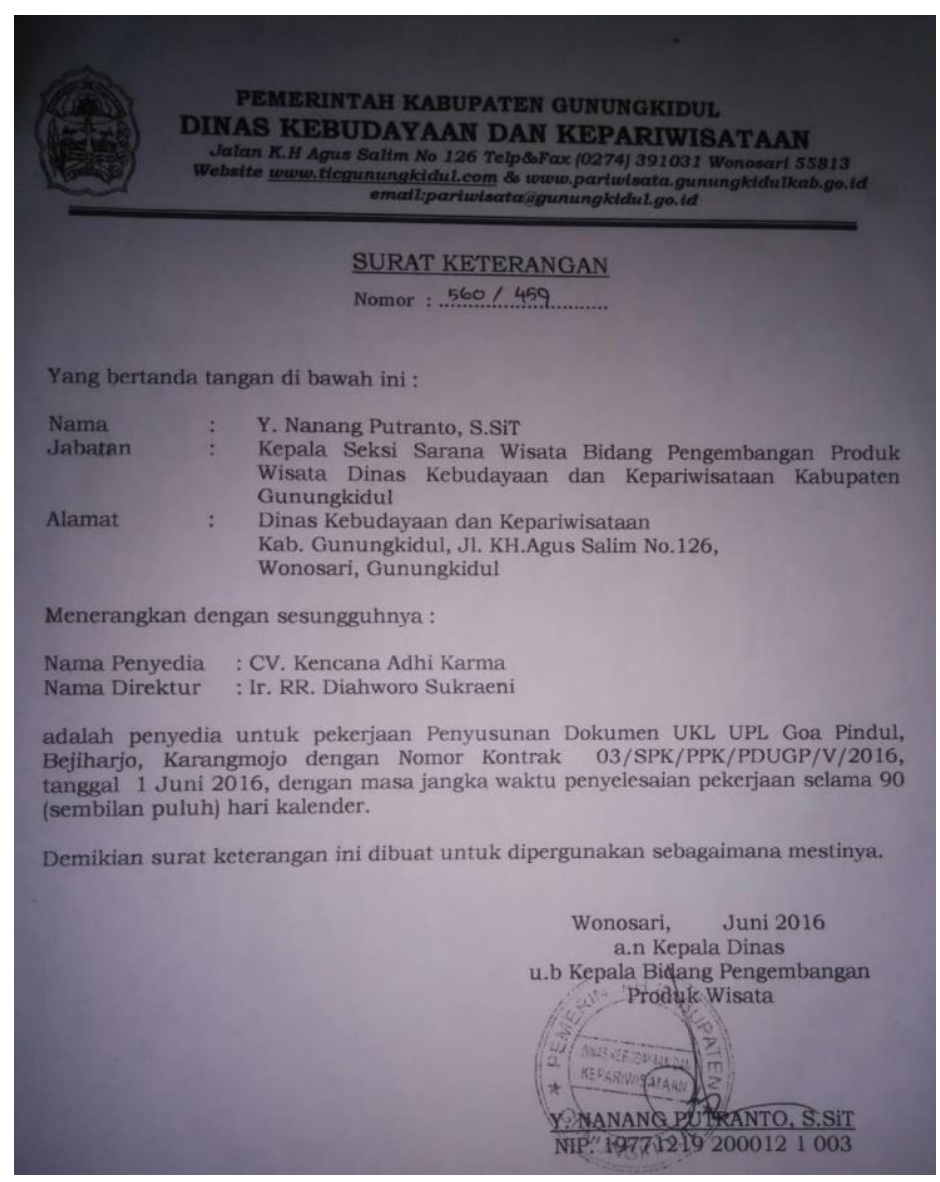

Gambar 4. Surat Izin Pembuatan Dokumen UKL/UPL (Dokumentasi Pribadi)

Upaya pengelolaan Lingkungan Hidup (UKL) dan Upaya Pemantauan Lingkungan Hidup (UPL) merupakan dokumen yang harus dibuat oleh setiap usaha/kegiatan yang tidak melakukan AMDAL (Analisis Mengenai Dampak Lingkungan) (Permen LH No. 17 Tahun 2002). Fungsi utama dibuatnya dokumen ini adalah sebagai pedoman pengelolaan dan pemantauan lingkungan hidup di Sistem Karst Pindul. Pembuatan dokumen ini dapat dikatakan terlambat. Pariwisata di Sistem Karst Pindul telah dimulai sejak tahun 2010, sedangkan dokumen UKL/UPL baru disusun semenjak tahun 2016. Hingga saat ini, pengerjaan dokumen tersebut belum selesai. 


\section{Pembentukan Kelompok Sadar Wisata (POKDARWIS)}

Dewa Beja merupakan POKDARWIS pertama yang terbentuk pada tahun 2010 (https://dewabejo.wordpress.com). Latar belakang pembentukan kelompok ini adalah untuk memaksimalkan potensi pariwisata di Sistem Karst Goa Pindul. Menurut Pramesti (2012), potensi pariwisata yang ada di wilayah ini adalah cave tubing Goa Pindul dan 12 goa wisata lain, Situs Purbakala Sokoliman, dan Monumen Jenderal Sudirman. Keberadaan POKDARWIS Dewa Beja terbukti mampu mengangkat pamor Goa Pindul menjadi destinasi andalan. Seperti yang diungkapkan Musadad (2013), wisata alam Goa Pindul mampu menarik sejumlah 122.423 wisatawan dan menyumbang 50\% dari total Pendapatan Asli Daerah (PAD) sektor pariwisata pada periode 2012-2013.

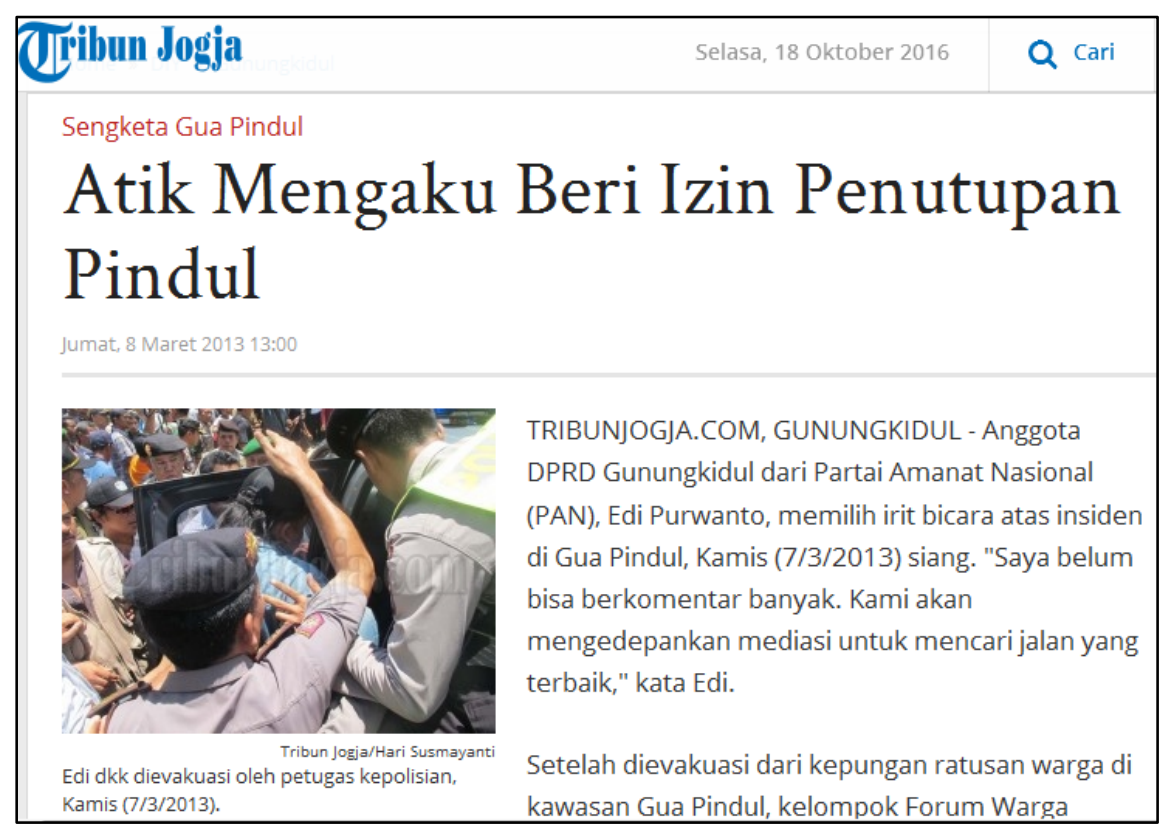

Gambar 5. Sengketa Lahan Goa Pindul

(http://jogja.tribunnews.com/2013/03/08/atik-mengaku-beri-izin-penutupanpindul)

Meskipun demikian, tingginya omset Goa Pindul menimbulkan konflik pengelolaan. Situs http://www.harianjogja.com menyatakan bahwa pada tahun 2013 terjadi konflik perebutan pengelolaan antara Atiek yang mengaku sebagai pemiliki lahan dengan kelompok pengelola wisata (Gambar 5). Pemerintah Daerah Kab.Gunungkidul mengambil tindakan dengan menerbitkan Perda No.5 Tahun 2013 mengenai Penyelenggaraan Keperawisataan. Salah satu isi dokumen ini mengatur pengelolaan wisata Goa Pindul yang diserahkan kepada pemerintah daerah. 
Setelah konflik selesai, sampai saat ini terdapat 13 operator pengelola wisata Goa Pindul. Seluruh operator tersebut saling bekerja sama untuk mengelola potensi wisata di Sistem Karst Goa Pindul. Berbagai program telah dilakukan untuk mengembangkan pariwisata, dua yang utama adalah pelatihan bahasa Inggris dan rescue. Menurut Agdityanissa (2015), pelatihan bahasa Inggris yang dilakukan oleh Operator Wirawisata rutin dilaksanakan setiap hari Rabu dan Jumat setelah jam kerja. Pelatihan ini menekankan pelayanan terhadap turis asing.

\section{Pengembangan Pariwisata melalui CSR (Corporate Social Responsibility Bank BCA}

Sebagai wujud tanggung jawab sosial perusahaan, Bank BCA melakukan berbagai program pengembangan pariwisata di Goa Pindul melalui operator Wirawisata (Gambar 6). Program-program tersebut terdiri dari pembangunan fasilitas \& infrastuktur wisata, pelatihan pelayanan wisata, dan produk layanan perbankan (http://www.bca.co.id). Seluruh program tersebut dilaksanakan pada bulan Juli hingga Agustus tahun 2014.

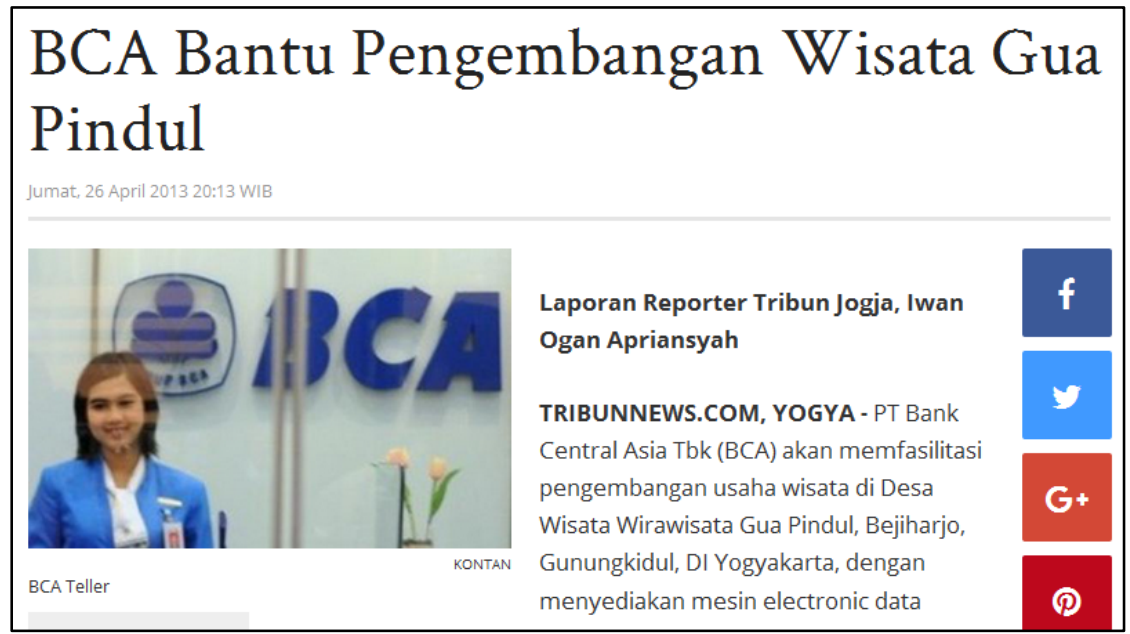

Gambar 6. Program CSR Bank BCA

(http://www.tribunnews.com/bisnis/2013/04/26/bca-bantu-pengembangan-

\section{Analisis}

wisata-gua-pindul)

Panizza (1996) mengungkapkan bahwa sumberdaya alam (geomorfologi) yang terlalu dieksploitasi oleh manusia akan menimbulkan suatu dampak tertentu. Sementara itu, aktivitas manusia yang menempati lingkungan dengan ancaman 
tertentu akan menimbulkan suatu risiko kehilangan. Gambar 7 menunjukkan hubungan antara manusia dengan sumberdaya lingkungannya.

Analisis terhadap konsep yang dijabarkan oleh Panizaa (1996) menunjukkan bahwa obyek wisata di Sistem Karst Pindul memerlukan penanganan serius. Geomorphological resource identik dengan Sistem Karst Goa Pindul yang memiliki sumberdaya sungai bawah tanah untuk kegiatan pariwisata. Geomorphological hazard identik dengan lokasi sistem karst yang memiliki bahaya banjir. Aktfititas pariwisata yang tidak memperhatikan kondisi lingkungan dapat menimbulkan dampak, seperti rusaknya kawasan karst, pencemaran air, dan berkurangnya kuantitas air. Selain itu, aktivitas tersebut juga dapat menimbulkan risiko, seperti hilangnya nyawa, harta benda, dan kerusakan fasilitas-infrastuktur akibat banjir.

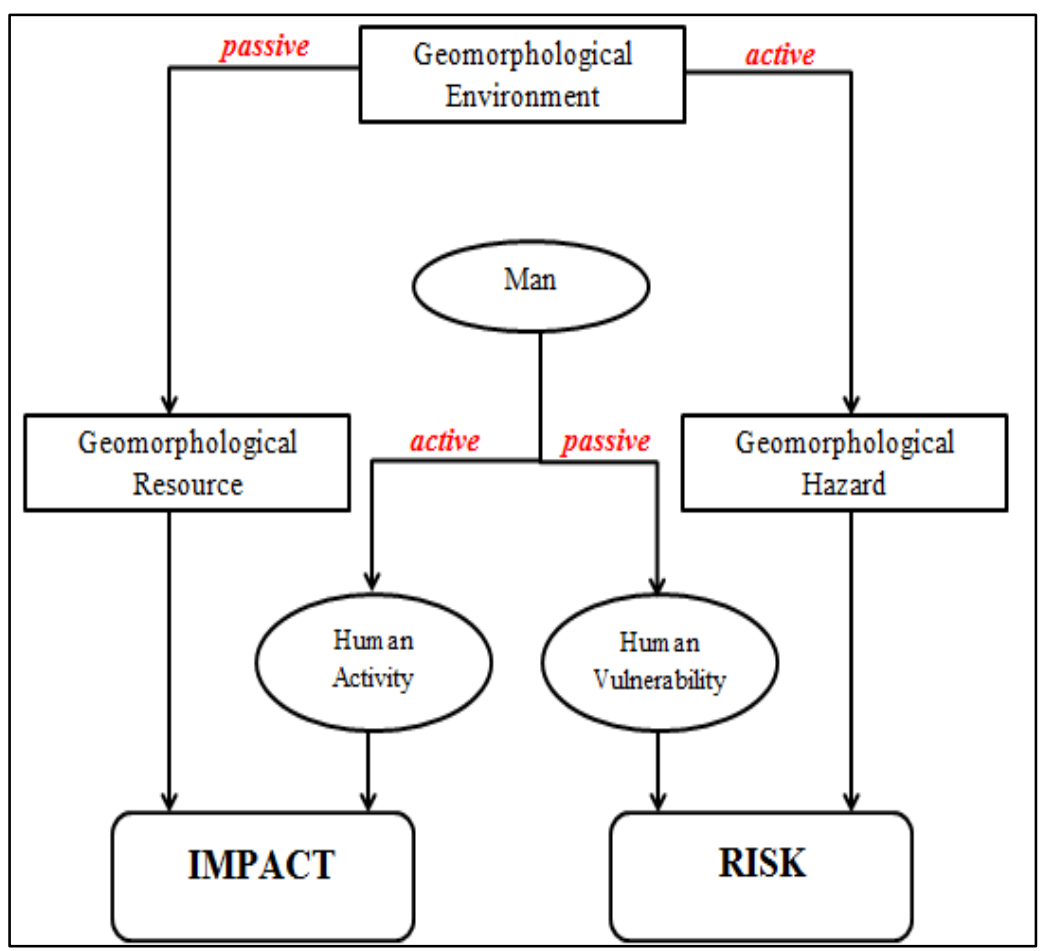

Gambar 7. Hubungan Manusia dengan Lingkungan Gemorfologinya (Panizza, 1996)

Berdasarkan permaslahan diatas, pariwisata di Sistem Karst Goa Pindul perlu dilakukan penanganan tertentu. Meskipun demikian, program-program yang selama ini dilakukan tidak ada yang berkaitan dengan kondisi lingkungan sistem karst, utamanya permasalahan banjir. Program-program yang telah dilakukan cenderung menekankan pada aspek ekonomi. Pelatihan bahasa dan rescue terhadap pemandu yang rutin dilakukan bertujuan utama untuk meningkatkan 
pelayanan. Sementara itu, pembangunan fasilitas dan infrastuktur juga memiliki tujuan utama untuk menarik banyak pengunjung.

Pembuatan dokumen UKL/UPL merupakan satu-satunya proram yang berhubungan dengan permasalahan lingkungan di Sistem Karst Pindul. Hingga saat ini dokumen tersebut belum selesai dibuat. Hasil analisis juga menunjukkan bahwa isi dokumen tersebut kurang memasukkan elemen-elemen yang berhubungan dengan banjir di kawasan Karst Goa Pindul.

\section{Input Gagasan}

Karakterisasi akuifer merupakan salah satu cara yang dapat dilakukan untuk mengenali perilaku hidrologi karst (White, 2002). Sistem Pindul sebagai suatu bentangalam karst menjadikan teknik-teknik yang biasa digunakan untuk mengkarakterisasi akuifer menjadi tidak berlaku (seperti hukum Darcy, pembuatan flownet, dan uji pompa). Hal tersebut terjadi karena akuifer karst memiliki rongga batuan yang terkadang homogen dan terkadang membentuk sistem perpipaan (Ford \& Williams, 2007). Oleh karena itu, penelitian mengenai karakteristik akuifer karst hampir semuanya dilakukan secara induktif (Adji, 2009). Menurut Adji dan Cahyadi (2016), terdapat enam cara yang dapat dilakukan untuk melakukan karakterisasi akuifer karst, yaitu:

1. analisis parameter hidrograf banjir,

2. perhitungan konstanta resesi,

3. pemisahan aliran dasar,

4. analisis respon debit terhadap hujan,

5. perhitungan derajat perkembangan akuifer karst,

6. analisis hidrokemograf.

Analisis parameter hidrograf banjir dan perhitungan konstanta resesi merupakan dua cara yang tepat untuk mengkarakterisasi akuifer di Sistem Karst Goa Pindul. Hal ini berkaitan dengan belum diketahuinya sifat-sifat banjir dan tingkat perkembangan karst. Penjelasan lebih lanjut mengenai dua konsep karakterisasi akuifer karst tersebut dapat dilihat dibawah ini.

\section{Analisis Parameter Hidrograf Banjir}

Hidrograf aliran merupakan gambaran grafis hubungan debit dengan waktu (Sri Harto, 1993). Sementara itu, hidrograf banjir merupakan kondisi hidrograf 
ketika aliran dalam kondisi paling besar (Gambar 8). Menurut Adji dan Cahyadi (2016), hidrograf banjir pada suatu outlet karst memcerminkan kondisi daerah tangkapan, besar kecilnya simpanan, cara pelepasan aliran, dan hubungan respon mataair atau sungai bawah tanah karst terhadap hujan.

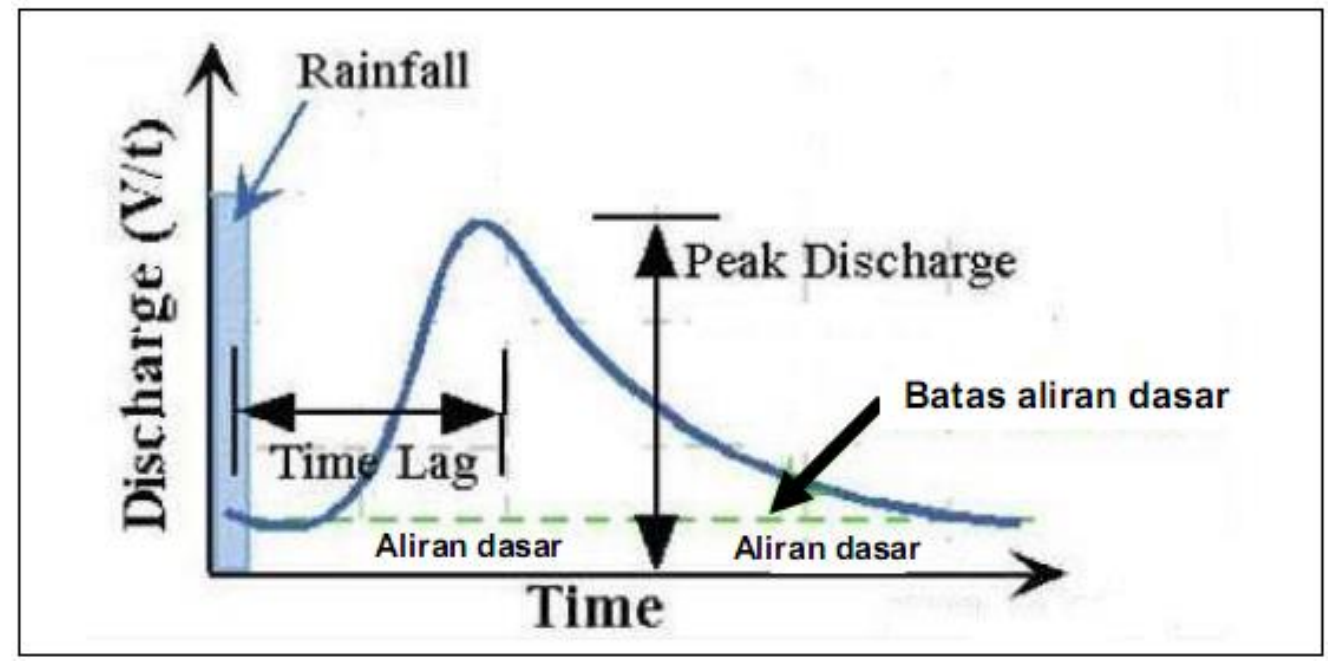

Gambar 8. Hidrograf Banjir (Adji \& Cahyadi, 2016)

Sifat-sifat banjir di Sistem Karst Goa Pindul dapat dijelaskan melalui analisis parameter hidrograf banjir. Parameter-parameter yang digunakan adalah time $\operatorname{lag}(\mathrm{Tc}) /$ waktu tunda, time to peak(Tp)/ waktu menuju puncak, debit puncak (Qp), dan time to baseflow $(\mathrm{Tb}) /$ waktu menuju aliran dasar. Tc menunjukkan waktu yang dibutuhkan sistem karst untuk terjadinya kenaikan debit ketika hujan pertama kali terjadi. Tp menunjukkan waktu yang dibutuhkan untuk mencapai debit maksimum ketika hujan maksimum terjadi. Qp menunjukkan debit aliran yang terjadi akibat suatu kejadian hujan tertentu. Tb menunjukkan waktu yang dibutuhkan untuk mencapai debit aliran dasar (normal) setelah terjadinya debit maksimum.

Analisis terhadap parameter-parameter diatas memberikan pemahaman mengenai sifat banjir di Sistem Karst Pindul. Misalnya adalah banjir besar akan terjadi di kawasan wisata ketika terjadi hujan dengan intensitas tertentu. Pengetahuan akan hal diatas dapat dijadikan landasan dalam menyusun sistem mitigasi bencana dan EWS (Early Warning System). Selain itu, nilai dari parameter-parameter hidrograf juga dapat menunjukkan sejauh mana kerusakan lingkungan karst terjadi. Menurunnya kuantitas dan kualitas air karst dapat dilihat 
melalaui naiknya fluktuasi tahunan, turunnya debit minimum, naiknya debit maksimum, dan turunnya prosentase aliran dasar (Adji, 2016).

\section{Perhitungan Konstanta Resesi dari Hidrograf Banjir}

Resesi merupakan bagian hidrograf yang dapat ditentukan persamaan umumnya (Linsley at al, 1975) (Gambar 9). Bentuk dari resesi hidrograf hanya dipengaruhi oleh karakteristik fisik saluran. Karakteristik yang dimaksud adalah ketika saluran melepaskan simpanan aliran setelah terjadinya banjir atau hujan..

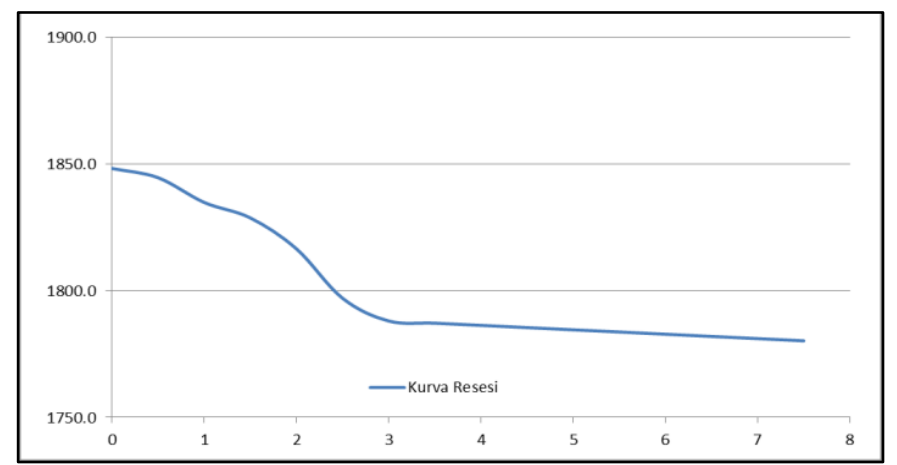

Gambar 9. Contoh Kurva Resesi (Dokumentasi Pribadi)

Persamaan umum suatu resesi hidrograf disebut sebagai konstata resesi. Konstanta resesi dihitung pada hidrograf yang memiliki kejadian banjir. Setelah terjadinya puncak banjir, hidrograf akan mengalami resesi yang dapat dihitung konstantanya. Persamaan kurva resesi menurut Barnes (1940, dalam Schulz, 1976) adalah sebagai berikut:

$$
\mathrm{Qt}=\mathrm{Q}_{0} \mathrm{e}^{-\mathrm{kt}}
$$

Keterangan:

Qt: Debit aliran waktu ke-t

$\mathrm{Q}_{0 \text { : }}$ Debit aliran waktu ke-(t-n)

$\mathrm{e}^{-\mathrm{k}}: \mathrm{Kr}$ (Konstanta resesi)

t: Waktu

Hasil ploting dalam skala semi-log menunjukkan bahwa persamaan tersebut linear, sehingga dapat diubah sebagai berikut:

$$
\begin{aligned}
& \ln \mathrm{Qt}=-\mathrm{Kr}(\mathrm{t}-\mathrm{t} 0)+\ln \left(\mathrm{Q}_{0}\right) \\
& \mathrm{Kr}=-1 /(\mathrm{t}-\mathrm{t} 0) \ln \left(\mathrm{Qt} / \mathrm{Q}_{0}\right)
\end{aligned}
$$

Schulz (1976) mengungkapkan bahwa selama kejadian resesi terdapat tiga komponen penyumbang utama, yaitu sreamflow (Krs), interflow (Kri), dan baseflow $(\mathrm{Kb})$. Persamaan dari ketiga resesi tersebut adalah sebagai berikut: 


$$
\mathrm{Kr}=\mathrm{Krs}+\mathrm{Kri}+\mathrm{Kb}
$$

Adji et al (2006) dan Adji (2009) menggunakan konsep konstanta resesi untuk mengkarakterisasi sifat aliran karst yang dicerminkan oleh komponen pelepasannya. Konsep tersebut mengidentikkan komponen streamflow dengan conduit, komponen interflow dengan fissure, dan komponen baseflow dengan diffuse. Schulz(1976) mengkategorikan nilai konstanta setiap komponen resesi yang dapat dilihat pada Tabel 1.

Tabel 1. Nilai konstanta resesi (Schulz, 1976)

\begin{tabular}{|c|c|}
\hline Komponen Aliran & Nilai Konstanta Resesi \\
\hline Sreamflow/ conduit & $0.05-0.2$ \\
\hline Interflow/ fissure & $0.5-0.8$ \\
\hline Baseflow/ diffuse & $0.85-0.98$ \\
\hline
\end{tabular}

Perhitungan konstanta resesi dapat mengetahui sejauh mana tingkat perkembangan karst di Sistem Pindul. Sistem yang didominasi oleh aliran conduit menandakan karst yang telah berkembang lanjut (White, 1988). Tingkat perkembangan karst tersebut juga akan menentukan sifat-sifat banjir yang dimiliki Sistem Pindul. Selain itu, perhitungan konstanta resesi juga dapat menunjukkan simpanan airtanah yang dimiliki wilayah ini. Oleh karena itu, perhitungan konstanta resesi dapat menjadi landasan rencana pembangunan pariwisata di Sistem Karst Pindul.

\section{Rencana Data yang Dikumpulkan dan Pemasangan Alat}

Data yang dibutuhkan untuk mewujudkan pariwisata tangguh baencana adalah debit aliran pengukuran lapangan, fluktuasi TMA (tinggi muka air) dari logger pencatat TMA, dan curah hujan dari logger iklim. Ketiga data diukur selama waktu satu tahun (variasi musim kemarau dan penghujan) dan pada tiga lokasi yang berbeda (Gambar 10). Ketiga lokasi tersebut adalah Obyek Wisata Goa Pindul (sebagai outlet utama Sistem Karst Pindul), Sinking stream Kedungbuntung (sebagai outlet sistem sungai permukaan), dan Goa Suruh (sebagai outlet sistem sungai bawah permukaan). 


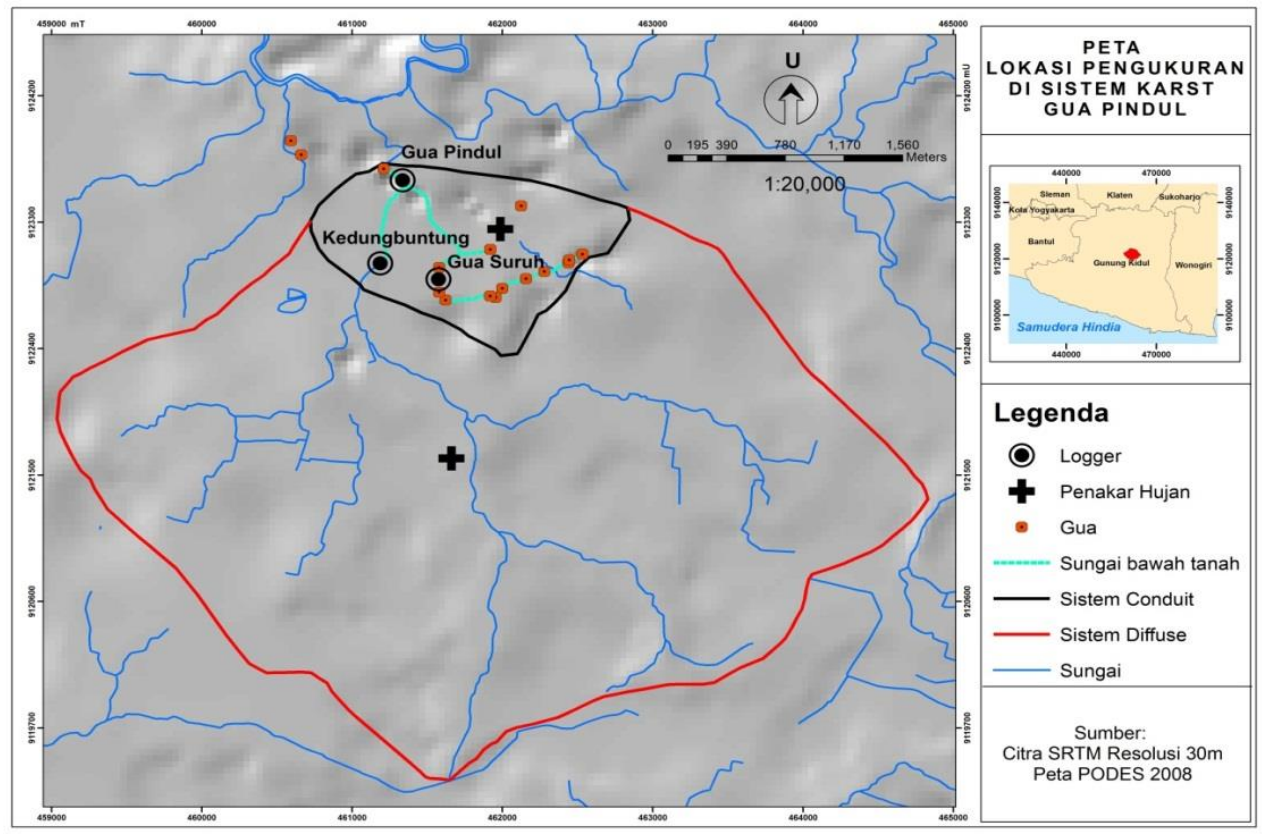

Gambar 10. Rencana Lokasi Pemasangan Alat dan Pengambilan Data

\section{REFERENSI}

Adji, T. N., et al. 2006. The Distribution Of Flood Hydrograph Recession ConstantOf Bribin River For Gunung Sewu Karst Aquifer Characterization. Dipublikasi ulang dari Gunung Sewu-Indonesian Cave and Karst Journal (Vol. 2. No.2).

Adji, T. N., 2009. Variasi Spasial-Temporal Hidrogeokimia dan Sifat Aliran UntukKarakterisasi Sistem Karst Dinamis Di Sungai Bawah Tanah Bribin, Kabupaten Gunungkidul, DIY. Desertasi. Fakultas Geografi UGM.

Adji, T. N., Cahyadi, A. 2016. Pentingnya Monitoring Parameter-Parameter Hidrograf Dalam Pengelolaan Airtanah di Kawasan Karst. National Workshop: Best Parctice of Sustainable Water Resources Management Based on Ecohydrology Approach, 12-14 Oktober 2016, Yogyakarta.

Adji, T.N., 2016. Bagaimana memprediksi kerusakan sumberdaya air karst, Makalah pada seminar internal "Konsolidasi Pengelolaan Ekosistem Karst dan pembahasan RPP Pengelolaan Ekosistem Karst", Kementrian Lingkungan Hidup dan Kehutanan, 6 Juni 2016,link download: https://www.academia.edu/25907154/BAGAIMANA_MEMPREDIKSI_K ERUSAKAN_SUMBERDAYA_AIR_KERUSAKAN_SUMBERDAYA_ AIR_KARST.

Agniy, Romza F. 2016. Kajian Hidrogeologi Karst Sistem Goa Pindul, Kecamatan Karangmojo, Kabupaten Gunungkidul. Skripsi. Fakultas Geografi UGM. 
Ford, D. and William, P., 2008. Karst Hydrogeology and Geomorphology. John Wiley \& Sons Ltd, The Atrium, Southern Gate, Chichester.

Linsley, JR., Kohler,M.A., Paulhus, J.L.H. 1975. Applied Hydrologi. New Delhi: Tata McGraw-Hill.

Musadad. 2014. Partisipasi Masyarakat Dusun Gelaran II dalam Pengembangan Wisata di Goa Pindul, Kabupaten Gunungkidul, Yogyakarta. Tesis. Fakultas Geografi UGM.

Panizza, M. 1996. Environmental Geomorphology. Amsterdam: Elesevier Science.

Sri Harto. 1993. Analisis Hidrologi. PT Gramedia Pustaka Utama, Jakarta.

Schulz, E.F. 1976. Problems in Applied Hydrology. Water Resources Publication, Colorado.

White, W.B. 1988. Geomorphology and Hydrology of Karst Terrains. New York: Oxford University Press.

White, W.B. 2002. Conceptual Models For Karstic Aquifers. Speleogenesis and Evolution of Karst Aquifers, 1 (1) January 2003, p.2, The Virtual Scientific Journal, www.speleogenesis.info. 